\title{
GENDER IN BANKING AND MORTGAGE BEHAVIOR
}

\author{
Štěpán Jurajda \\ Radek Janhuba
}

Charles University

Centerfor Economic Research and Graduate Education

Academy of Sciences of the Czech Republic

Economic Institute

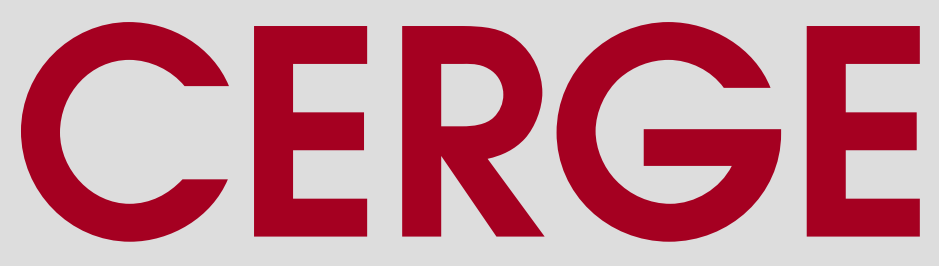




\title{
Working Paper Series $\quad 564$ (ISSN 1211-3298)
}

\section{Gender in Banking and Mortgage Behavior}

\author{
Štěpán Jurajda
}

Radek Janhuba

\section{CERGE-EI}

Prague, May 2016 
ISBN 978-80-7343-371-0 (Univerzita Karlova v Praze, Centrum pro ekonomický výzkum a doktorské studium)

ISBN 978-80-7344-377-1 (Národohospodářský ústav AV ČR, v. v. i.) 


\title{
Gender in Banking and Mortgage Behavior
}

\author{
Štěpán Jurajda and Radek Janhuba \\ CERGE-EI
}

May 2016

\begin{abstract}
Compared to men, women, even financial professionals, exhibit higher risk aversion. We exploit random assignment of clients to banking advisors ('private bankers') in a large Czech bank to study the effects of advisor gender on the probability of mortgage issuance and on the probability that a newly issued mortgage is insured, which we interpret as corresponding to risk averse mortgage behavior. Male advisors do not substantially affect the chances that their clients will take a new mortgage, but the mortgages that they issue are dramatically less likely to be insured, particularly so for female clients who never had an insured loan with the bank.
\end{abstract}

JEL Codes: G21, G32, J16.

Keywords: Banking Advisors, Mortgage Insurance

Acknowledgements CERGE-EI is a joint workplace of the Center for Economic Research and Graduate Education, Charles University, and the Economics Institute of the Czech Academy of Sciences. Jurajda is Research Affiliate at CEPR, London and Research Fellow at IZA, Bonn. This research has been supported by the Czech Science Foundation (grant P402/12/G130).

Address CERGE-EI, Charles University in Prague and the Czech Academy of Sciences, Politickych veznu 7, Prague, Czech Republic. E-mail: stepan.jurajda@cerge-ei.cz 


\section{Introduction}

There is growing interest in the gender of contracting parties involved in lending, specifically in gender differences in the behavior of loan officers. This interest is motivated by the strong evidence of higher risk aversion among women (e.g., Eckel et al., 2008; Charness and Gneezy, 2012), which is reflected in financial decisions (e.g., Barber and Odean, 2001; Sapienza et al., 2009; Neelakantan, 2010), even decisions made by financial professionals (Dwyer et al., 2002; Beckmann and Menkhoff, 2008). ${ }^{1}$

The little evidence available on female loan officers is in line with the general thrust of the literature: The findings of Bellucci et al. (2010) are consistent with female loan officers (in an Italian bank) being more risk-averse than their male colleagues. Beck et al. (2013) suggest that (in an Albanian bank) loans screened by female loan officers have a lower likelihood of turning problematic than loans handled by male loan officers.

Gender differences in risk attitudes may be particularly important for the growing share of household financial decisions that are made with the help of a financial or banking advisor (Berg et al., 2010; Roszkowski and Grable, 2005; Earnst \& Young, 2010). Direr and Visser (2013) study the riskiness of investment decisions made by adviser-client pairs in a large French financial institution. They find that investment accounts opened with a male advisor exhibit higher equity shares (i.e., are riskier), especially for male customers. ${ }^{2}$

In this paper, we extend the literature on gender in retail banking by studying a 2013 campaign, in which over 35 thousand clients of a large Czech bank were assigned (for the first time) to a banking advisor ('private banker') at their branch. The campaign was intended to extend the availability of banking advisors to clients of the bank, which generates a large

\footnotetext{
${ }^{1}$ A separate body of work focuses on gender discrimination and gender differences in the availability of commercial or consumer credit; see Alesina et al. (2013), Asiedu et al. (2012) or Bellucci et al. (2010).

${ }^{2}$ In the only study focusing on the gender makeup of borrower-loan officer pairs, Beck et al. (2012) do not ask about risk taking, but examine the effect of own-gender preferences on loan rates and maturities. Their findings imply that loan applicants (quasi-randomly) assigned to Albanian loan officers of the opposite sex receive somewhat less favorable loan terms and are less likely to return for a second loan.
} 
part of its revenue from consumer loans and mortgages. Our analysis focuses on mortgages, which represent some of the largest and most important financial decisions made by typical clients of retail banks in the Czech Republic, where, according to local surveys, only $10 \%$ of the population invests on the stock market.

Relying on the random assignment of advisors to clients, we ask, separately for male and female clients, whether the gender of the advisor affects the probability of a client taking a mortgage within 21 to 27 months of advisor assignment, and, conditional on a mortgage being issued, whether the gender of the advisor affects the probability that the mortgage is insured. ${ }^{3}$ The bank's policy is to offer mortgage insurance, which covers mortgage payments in the case of injury, death, or loss of employment, but individual banking advisors may differ in how effectively they sell mortgage insurance. ${ }^{4}$ We interpret the purchase of insurance as a proxy measure for risk averse mortgage behavior. ${ }^{5}$ Further, we proxy for clients' preassignment risk attitudes using a similar indicator - the client's experience with an insured as opposed to uninsured consumer loan with the bank.

Our estimates imply that male advisors do not sell more mortgages than female advisors to their clients, but that the mortgages they sell are dramatically less likely to be insured. When examining the heterogeneity of the male-advisor effect, we find that male advisors sell more mortgages than female advisors to male clients with previous experience with an uninsured consumer loan, i.e., to the possibly more risk-inclined clients. Similarly, the negative effect of a male advisor on mortgage insurance is absent for female clients who have experience with insured loans - possibly a less risk-inclined group of clients. To the extent

\footnotetext{
${ }^{3}$ Mortgage insurance not only reduces the risk exposure of lenders, it also facilitates the creation of secondary mortgage markets (Bardhan et al., 2006). As in most developed countries, mortgage insurance in the Czech Republic is a private product, not a government-sponsored program (Joint Forum, 2013).

${ }^{4}$ The advisors have little control over mortgage interest rates, which are set according to the bank's formulaic rate policy. They can apply for exceptions from the policy, but such exceptions are seldom granted.

${ }^{5}$ The demand for mortgage insurance is substantially lower among over-confident Dutch households (Cox and Zwinkels, 2016; Cox et al. 2015).
} 
that insurance take-up corresponds to riskiness of borrowing, our results are thus consistent with male advisors increasing the risk content of mortgage decisions taken by their clients, perhaps especially so for the more risk-inclined clients.

\section{Data}

The banking advisor assignment campaign we study started in September 2013 and ended in March 2014. Each month, approximately five thousand clients were assigned to an advisor at their branch. In total, we observe 35,945 clients assigned to 580 advisors in 147 branches. The monthly assignment process targeted clients in each branch who had above-threshold balance sums with the bank and the assignment to a particular advisor was randomized each month. ${ }^{6}$ We observe an indicator of client mortgage purchases between the moment of assignment and December 2015 so that we observe mortgage take-up for each client over a period of 21 to 27 months. Assigned advisors process all sales of new credit products to clients. While advisors record the type of advising contact they have with their clients (meetings at the branch and telephone and email contacts), these records are noisy and are not reliably archived in the bank's databases. It is plausible that some of the clients assigned to advisors chose not to use their advising services. Hence, our mortgage take-up estimates correspond to intention-to-treat (ITT) parameters. ${ }^{7}$

From the original set of 35,945 clients assigned to advisors, we drop the 5,691 (16\%) clients for whom the assignment was not carried out (e.g., due to missing client contact information). Further, we drop the 7,041 (20\%) cases with missing data or where during our sample frame, there was a change of advisor, leaving 23,213 client observations. ${ }^{8}$ For each

\footnotetext{
${ }^{6}$ We started collaborating with the bank in May 2013, while the campaign was being prepared.

${ }^{7}$ We do not observe the timing or intensity of advising, which precludes us from studying the treatment dynamics. It is typical to focus on ITT effects in such situations as argued, e.g., in Cellini et al. (2010).

${ }^{8}$ Fortunately, the data dropping appears random with respect to the gender structure of the client-advisor pairs: it does not affect the gender structure of the sample.
} 
client, we observe whether the mortgage they purchase is insured. We also observe two types of client information: clients' outstanding loan balance as of the moment of advisor assignment and clients' pre-assignment experience with loan products with the bank. Specifically, we divide clients into three categories: the $20 \%$ who have experience with an insured loan or mortgage, the $25 \%$ who had taken only uninsured loans or mortgages, and the remaining $55 \%$ who never had a consumer loan or a mortgage with the bank. While assignment was random and the control variables we observe, including the gender of the clients, are balanced across advisors' gender, ${ }^{9}$ in a subset of our analysis we condition on client characteristics with the goal of identifying potentially heterogenous effects of advisors' gender on clients' mortgage behavior. We consider the experience with an insured (as opposed to an uninsured) loan or mortgage as a signal of the client being more risk averse.

During the roughly two years we observe for each client, $3.42 \%$ of men and $1.77 \%$ of women take a new mortgage. Of the 628 new mortgages, 450 are thus taken by men. Further, $56 \%$ of newly issued mortgages are insured and the share of insured mortgages is similar for female and male clients. Table 1 presents descriptive characteristics of the clients together with the gender of their advisors. Male clients are more likely to have previous loan experience, particularly so for uninsured loans.

Table 1: Descriptive Characteristics

\begin{tabular}{lcc}
\hline & Female Clients & Male Clients \\
\hline Mean outstanding loan balance as of assignment & 0.248 & 0.405 \\
in millions of CZK & & \\
\% with insured loan experience & 16.1 & 23.2 \\
\% with uninsured loan experience & 19.7 & 29.0 \\
\% without previous loan experience & 64.2 & 47.8 \\
\% taking a new mortgage & 1.77 & 3.42 \\
\% of newly issued mortgages insured & 56.2 & 56.1 \\
\% with male advisors & 18.2 & 18.2 \\
N & 10,046 & 13,167 \\
\hline
\end{tabular}

\footnotetext{
${ }^{9}$ Balancing tests are available upon request.
} 


\section{Results}

Our first question is whether having a male (as opposed to female) advisor affects the probability that a given client will take a new mortgage. Private bankers are offered to clients, in some significant part, with the aim of increasing awareness about the products offered by the bank and thus selling financial products. We do not ask whether private bankers sell additional mortgages that would not be sold in their absence. Instead, we ask whether the gender of the assigned advisor affects one of the key outcomes of advising - the purchase of a mortgage. Table 2 shows the estimates corresponding to the probability of purchasing a new mortgage. ${ }^{10}$ The gender of one's 'private banker' does not affect the probability of mortgage purchase for either female or male clients in columns (1) and (3), respectively.

Does the advisor's gender affect different types of clients differently? There is some evidence of heterogenous effects for male clients in column (4). First, clients of both genders who have previous loan experience (as opposed to no previous loan experience with the bank) are more likely to take a mortgage. Similarly, clients with larger outstanding balances as of assignment are more likely to take new mortgages. These effects are both qualitatively and quantitatively similar for male and female clients. Second, if a male client who has previous loan experience, but never used loan insurance with the bank, is assigned to a male advisor, he is about 2 percentage points more likely to purchase a mortgage. If clients with previous uninsured loan experience have lower risk aversion (compared to clients with previous insured loans and clients without loan experience), then the estimated parameter corresponds to male advisors leading their relatively risk-loving clients to take additional mortgages they would not have taken with a female advisor.

Our second question is whether the gender of the advisor affects whether a mortgage that has been purchased is insured or not. Given that advisors' gender does not have a major effect on mortgage take-up for almost all client types, we assume that to the first

\footnotetext{
${ }^{10}$ All of the regressions presented in this section also control for the number of months after assignment over which we observe each client.
} 
that having a male 'private banker' dramatically lowers the probability that a newly issued mortgage is insured. The average insurance take-up rate is $56 \%$. A randomly assigned male (as opposed to female) advisor lowers the take-up rate by over 11 percentage points for male clients and by almost 25 percentage points for female clients. Columns (2) and (4) imply that having previous experience with loan insurance has a first-order effect on mortgage insurance take-up. The negative male-advisor effect on insurance take-up disappears for women (as well as men, even though here the male-advisor interaction is not statistically significant) with previous insured loan experience. There is no statistically significant evidence of male advisors affecting insurance take-up differently for other types of clients.

Table 3: Probability of Mortgage Insurance Takeup

\begin{tabular}{|c|c|c|c|c|}
\hline \multirow[t]{2}{*}{ Client Gender: } & \multicolumn{2}{|c|}{ Women } & \multicolumn{2}{|c|}{ Men } \\
\hline & $(1)$ & $(2)$ & $(3)$ & $(4)$ \\
\hline \multirow[t]{2}{*}{ Male advisor } & -0.2428 & -0.3373 & -0.1147 & -0.1130 \\
\hline & $(0.0911)$ & $(0.1431)$ & $(0.0687)$ & $(0.1215)$ \\
\hline \multirow[t]{2}{*}{ Insured loan experience } & & 0.5306 & & 0.6562 \\
\hline & & $(0.0788)$ & & $(0.0434)$ \\
\hline Insured loan experience & & 0.2939 & & 0.1047 \\
\hline * Male Advisor & & $(0.1583)$ & & $(0.1228)$ \\
\hline \multirow[t]{2}{*}{ Uninsured loan exp. } & & -0.1603 & & -0.0048 \\
\hline & & $(0.1146)$ & & $(0.0594)$ \\
\hline Uninsured loan exp. & & 0.2064 & & 0.0153 \\
\hline * Male advisor & & $(0.2777)$ & & $(0.1570)$ \\
\hline Loan balance as of & & -0.0873 & & -0.0389 \\
\hline of assignment & & $(0.0328)$ & & $(0.0134)$ \\
\hline Loan balance as of asg. & & 0.0547 & & 0.0141 \\
\hline * Male advisor & & $(0.0962)$ & & $(0.0279)$ \\
\hline $\mathrm{N}$ of mortgages & \multicolumn{2}{|c|}{178} & \multicolumn{2}{|c|}{450} \\
\hline $\mathrm{N}$ of advisors & \multicolumn{2}{|c|}{133} & \multicolumn{2}{|c|}{251} \\
\hline \multicolumn{5}{|c|}{$\begin{array}{l}\text { Notes: Each entry shows an OLS coefficient from a regression ex- } \\
\text { plaining the binary decision to purchase mortgage insurance. Stan- } \\
\text { dard errors in parentheses are based on clustering at the advisor level. }\end{array}$} \\
\hline
\end{tabular}




\section{Conclusions}

Our analysis provides the first available look at gender-in-banking effects on mortgage decisions. While we study only the crudest measures of mortgage behavior, namely mortgage purchase and mortgage insurance take-up, our estimates benefit from random assignment of banking advisors ('private bankers') to a large set of clients. Our results are in line with the findings of the small literature on loan officers' gender. Specifically, our results are consistent with female 'private bankers' being more risk averse and advising their clients on take-up of mortgage insurance in a fashion consistent with their own risk preferences. This could be an important issue in countries, such as the Czech Republic, where mortgages only became available recently, ${ }^{13}$ such that consumers are unlikely to have sophisticated knowledge of the available spectrum of mortgage parameters and their importance. Given the growing importance of banking advisors in retail banking, future work is needed to explore this issue with more detailed data on a larger set of financial decisions.

\footnotetext{
${ }^{13}$ Prior to the year 2000, the mortgage market was nearly non-existent in the Czech Republic. According to the Czech National Bank, the volume of household mortgage debt increased over 22 times between 2003 and 2013.
} 


\section{Bibliography}

Alesina, A., Lotti, F., and P. Mistrulli (2013) "Do women pay more for credit? Evidence from Italy," Journal of the European Economic Association 11, 45-66.

Asiedu, E., Freeman, J., and A. Nti-Addae (2012) "Access to credit by small businesses: How relevant are race, ethnicity, and gender?" American Economic Review 102, 532537.

Barber, B. M., and T. Odean (2001) "Boys Will Be Boys: Gender, Overconfidence, and Common Stock Investment," Quarterly Journal of Economics, 116, p. 261-292.

Bardhan, A., Karapandža, R., and B. Urošević (2006) "Valuing Mortgage Insurance Contracts in Emerging Market Economies," Journal of Real Estate Finance and Economics, 32(1): 9-20.

Beck, T., Behr, P., and A. Guettler (2013) "Gender and banking: Are women better loan officers?" Review of Finance, 17 (4): 1279-1321.

Beck, T., Behr, P., and A. Madestam (2012) "Sex and credit: Is there a gender bias in lending?" European Banking Center Discussion Paper 17.

Beckmann, D., and L. Menkhoff (2008) "Will Women Be Women? Analyzing the Gender Difference among Financial Experts," Kyklos 61(3), p. 364-384.

Bellucci, A., Borisov, A., and A. Zazzaro (2010) "Does gender matter in bank-firm relationships? Evidence from small business lending," Journal of Banking \& Finance 34, $2968-2984$.

Berg, N., Monti, M., Gigerenzer, G., and L. Martignon (2010) "Financial Advisors and Their Clients: Information Search and Portfolio Choice among Bank Customers," SSRN.

Cellini, S.R., Ferreira, F., and J. Rothstein (2010) "The Value of School Facility Investments: Evidence from Dynamic Regression Discontinuity Design," Quarterly Journal of Economics, 125(1): 215-261.

Charness, G., and U. Gneezy (2012) "Strong Evidence for Gender Differences in Risk Taking," Journal of Economic Behavior \& Organization 83(1): 50-58.

Cox, R.H.G.M., \& R.C.J. Zwinkels (2016) "Mortgage Insurance Adoption in the Netherlands," Real Estate Economics, forthcoming. 
Cox, R.H.G.M., Brounen, D., and P. Neuteboom (2015) "Financial Literacy, Risk Aversion and Choice of Mortgage-type by Households," The Journal of Real Estate Finance and Economics, 50(1): 74-112.

Direr, A., and M. Visser (2013) "Portfolio choice and financial advice," Finance 34(2): $35-64$.

Dwyer, P.D., Gilkenson, J.H., and J.A. List (2002) "Gender Differences in Revealed Risk Taking: Evidence From Mutual Fund Investors," Economics Letters 76, 151-58.

Earnst \& Young (2010) Understanding customer behavior in retail banking: The impact of the credit crisis in Europe. Earnst \& Young.

Eckel, C.C., and P.J. Grossman (2008) "Men, Women and Risk Aversion: Experimental Evidence," in: Plott, C.R., and V.L. Smith (eds.), Handbook of Experimental Economics Results, Vol. 1, p. 1061-1072.

Joint Forum (2013) "Mortgage Insurance: Market Structure, Underwriting Cycle, and Policy Implications - Consultative Document," Basel Committee on Banking Supervision, Joint Forum.

Neelakantan, U. (2010) "Estimation and Impact of Gender Differences in Risk Tolerance," Economic Inquiry 48(1), p. 228-233.

Roszkowski, M.J., and J. Grable (2005) "Gender Stereotypes in Advisors' Clinical Judgments of Financial Risk Tolerance: Objects in the Mirror Are Closer than They Appear," Journal of Behavioral Finance 6(4), p. 181-191.

Sapienza, P., Zingales, L., and D. Maestripieric (2009) "Gender differences in financial risk aversion and career choices are affected by testosterone," Proceedings of the National Academy of Sciences, 106(36): 15268-15273. 


\begin{abstract}
Abstrakt
Ženy obecně vykazují vyšší averzi k riziku než muži a toto srovnání je platné i mezi zaměstnanci ve finančním sektoru. V této krátké studii využíváme náhodného přiřazení bankovních poradců (soukromých bankéřů) ke klientům k zodpovězení otázky, zda prriřazení poradce versus poradkyně mění pravděpodobnost, že si klient vezme novou hypotéku, a dále pravděpodobnost, že je hypotéka pojištěná. Výsledky neukazují na významný vliv poradce vs. poradkyně na prodej hypoték, ale vyplývá z nich, že hypotéky prodané poradci mají výrazně nižší míru pojištění než hypotéky prodané poradkyněmi. Tento rozdíl je obzvláště patrný pro klientky, které nemají zkušenosti s pojišt'ováním úvěrů.
\end{abstract}




\section{Working Paper Series}

ISSN 1211-3298

Registration No. (Ministry of Culture): E 19443

Individual researchers, as well as the on-line and printed versions of the CERGE-EI Working Papers (including their dissemination) were supported from institutional support RVO 67985998 from Economics Institute of the ASCR, v. v. i.

Specific research support and/or other grants the researchers/publications benefited from are acknowledged at the beginning of the Paper.

(c) Štěpán Jurajda and Radek Janhuba, 2016

All rights reserved. No part of this publication may be reproduced, stored in a retrieval system or transmitted in any form or by any means, electronic, mechanical or photocopying, recording, or otherwise without the prior permission of the publisher.

Published by

Charles University in Prague, Center for Economic Research and Graduate Education (CERGE) and

Economics Institute of the CAS, v. v. i. (EI)

CERGE-El, Politických vězňů 7, 11121 Prague 1, tel.: +420 224005 153, Czech Republic.

Printed by CERGE-EI, Prague

Subscription: CERGE-EI homepage: http://www.cerge-ei.cz

Phone: + 420224005153

Email: office@cerge-ei.cz

Web: http://www.cerge-ei.cz

Editor: Jan Zápal

The paper is available online at http://www.cerge-ei.cz/publications/working_papers/.

ISBN 978-80-7343-371-0 (Univerzita Karlova v Praze, Centrum pro ekonomický výzkum a doktorské studium)

ISBN 978-80-7344-377-1 (Národohospodářský ústav AV ČR, v. v. i.) 
CERGE-EI

P.O.BOX 882

Politických vězňů 7

11121 Praha 1

Czech Republic http://www.cerge-ei.cz 